\title{
Student support to enhance student living and learning at a South African University
}

\section{Coetzee, Isabella ${ }^{a}$}

${ }^{a}$ Faculty of Humanities, Tshwane University of Technology, South Africa.

\begin{abstract}
Quantitative measures show that the higher education system in South Africa remains inefficient and this reality poses significant challenges to all universities. The Faculty of Humanities at the Tshwane University of Technology has added a Student Support Programme to the existing institutional student support structures. In this article, the author reflects on the experiences of student supporters who were appointed in 2014 and 2015 for the enhancement of students' living and learning to improve success in the Faculty of Humanities. The findings indicated that this programme has indeed improved the academic performance and personal circumstances of hundreds of students. The under-preparedness of students entering South African higher education institutions was highlighted as a major obstacle in academic performances. The majority of students who are supported by this programme experience intense personal and social challenges that are by and large brought about by and as the result of severe financial needs. The student supporters were adamant in their departing statement that much more had to be done over and beyond the general and existing approach and support structures at the Tshwane University of Technology to support these students.
\end{abstract}

Keywords: Student support; Student living; Student learning. 


\section{Introduction}

According to the National Development Plan (NDP), university success rates in South Africa are relatively low compared to similarly developed countries (NPC, 2011). The problems of low participation, retention and graduation rates are a huge challenge and raise significant concerns about the productivity of the system and the high costs to government and institutions (DOE, 2001; DHET, 2011; CHE, 2013; NPC, 2011; Lewin \& Mawoyo, 2014). A cohort study conducted by the Council of Higher Education (CHE) shows that only 50\% of students entering higher education will ever graduate (CHE, 2013).

Tshwane University of Technology (TUT), with 57000 students is the largest residential university in South Africa. The Faculty of Humanities with 13000 students is one of seven faculties and is situated in Soshanguve, a black township in the Pretoria area of the Gauteng Province. Although higher education in South Africa has become more accesible over the past two decades, it is still unaffordable for the majority of historically disadvantaged students from poor financial backgrounds. Many of our the students come from households of unemployed parents. The HIV/AIDS pandemic in South Africa caused the death of many parents and these orphans depend on the assistance of relatives, community members or the state to be able to enter into higher education. Students who managed to get support from sponsors are mostly accommodated in the hostels on campus but many students are obliged to seek alternative accommodation in the surrounding area and this is not always without risk. When the majority of the students registered with the faculty have to live and learn under such difficult circumstances, the average success rate of $78 \%$ over the past 3 years is aceptable but the graduation rate of $21 \%$ and dropout rate of $28 \%$ from the 2011 cohort, is a matter of concern. Steps aimed at supporting and guiding our students towards academic success were desperately needed.

For these reasons the Faculty of Humanities has decided to add a Student Support Programme to the existing institutional support structures such as subject tutors, mentors and professional councellors to address and contribute in enhancing the quality of living and learning of students. In this article, the author reflects on the experiences of the student supporters appointed in this programme over the past two years in order to indicate the effectiveness of this intervention with specific reference to academic and non-academic factors.

\section{Literature review}

Student success is complex and multi-dimensional. Lewin and Mawoyo (2014) identify two interrelated factors that impact on student success, namely academic and non-academic factors. Academic factors can be student-related or staff-related. For the purpose of this 
article the author used this classification with her own interpretation. Student-related factors include aspects such as students' preparedness for tertiary study and their attitude and approach to further study. Staff-related academic factors, which for the purpose of this article will not be attended to, include staff members' approach to pedagogy, their attitudes and skills and their ability to handle pressures related to time and workload. Non-academic factors refer to students' personal, social and financial challenges, their living conditions and socio-cultural and systemic factors.

In 2014, the Directorate of Quality Promotion (DQP) at TUT conducted a survey on the First Year Initial Experience (FYIE). Findings from the FYIE report (TUT, 2015), specifically from the approximately 700 respondents of the Faculty of Humanities, assisted to strategise this intervention with the aim of enhancing student success.

\section{Student Support Programme}

To be selected as facilitators for the Student Support Programme offered by the faculty, senior students should not only be academic achievers. They should have shown leadership skills, have good communication skills and should be able to manage their own academic programmes as such that their workload as student supporters does not negatively impact on their academic performance.

In 2014 eight senior student facilitators were appointed and each was assigned to a specific academic department in the faculty for 19 hours per week. This number increased to ten student supporters in 2015. They worked closely with head of departments, subject lecturers, subject tutors and student supporters as well as with TUT's division of Student Development and Support (SDS). Regular feedback sessions with the Dean were honoured and they had to submit written semester reports about the progress of each student at risk.

Student supporters are available for students who are not performing well academically or who experience challenges with regard to non-academic issues that have an impact on their success. The tasks of student supporters can be summarised as follows:

- At the beginning of the year they identify students who are academically at risk, based on the final results of the previous year or students who have not performed satisfactory during the first test series of the year.

- $\quad$ Student supporters arrange personal meetings with students. The student supporter introduces himself/herself to the student and explain the purpose of the intervention.

- $\quad$ After the initial consultation, a student is categorised as a high or low risk student and a student file is opened. 
- The student at risk is then referred to the subject tutors, mentors or professional counsellors.

- $\quad$ The student supporter stays in contact with the recommended support structure and requests regular reports on the student's progress.

- $\quad$ The student supporter monitors the student's progress after each assessment cycle and considers transfer the student to the higher or lower risk category.

- The student supporter constantly identifies and contacts new underperforming students based on test results.

\section{Research question and methodology}

To determine the value of the support programme, the following research question needs to be answered: How effective is the Student Support Programme to enhance students' living and learning at a South African University?

A qualitative research approach was followed because it provided the means to investigate the complex ways people interact in their everyday lives which enabled the researcher to increase her understanding of people's experiences and perspectives (Stringer, 2004). The participants comprised second, third and fourth year students appointed as student supporters.

Apart from regular feedback sessions with the student supporters during their term of service/appointment, semi-structured interviews (Leedy \& Ormrod, 2005; Mertler, 2009) were also conducted with each participant towards the end of their term. Document analysis as another data collection instrument was utilised. Analysing the semester reports ensured that the researcher didn't miss the truth of the examined phenomenon, namely student success (Lynch, 2010).

\section{Findings}

Since 2014, a total number of 863 students at risk have been supported and/or guided by student supporters. The findings are discussed under themes which represent academic and non-academic factors that impact on student success in higher education.

\subsection{Academic factors that impact on student success}

The following student-related academic factors are discussed: Under-preparedness of students and their attitudes and approach to their studies. 


\section{Under-preparedness of students}

The majority of schools from which the Faculty's students come, do not adequately prepare learners for tertiary education. Inadequacies in the secondary school system (the details of which are not relevant for purposes of this article) are seen as a major stumbling block for student success. A student supporter stated that "The huge gap between school and university needs to be closed so that struggling students can progress".

Most students from rural schools agreed that English as the language of instruction and in most cases, their third language, causes major problems for them. It also transpired that students are scared and hesitant to ask questions in class or to seek assistance from lecturers and tutors. One student supporter referred to the remark of a student who was in need of support: "I don't want them [lecturers] to think that I do not belong here, so it is better to keep quiet." This language barrier contributes to some students' withdrawing from group discussions or refraining from asking questions in class. Student supporters speak various African languages which made it easier for students in a country with 11 official languages, to express themselves more clearly in their mother tongue during conversations.

\section{Students' attitudes and approach to studies}

Linked to the issue of seriously lacking proper career guidance at schools, are the attitudes towards and their approach to studies at tertiary level. Some students see themselves as victims. Everybody else is responsible for their failures. They demand relief in some or other format and if it does not arrive, the system has let them down. The language problem and their weak language competecy, contributes to them losing faith which all culminate in the attitude of despair. Student supporters elucidated how they struggle to encourage students who have already given up.

\subsection{Non-academic factors that impact on student success}

The following non-academic factors were identified as themes for discussion: personal, social and financial challenges, living conditions, socio-cultural and systemic factors.

\section{Personal, social and financial challenges of students}

It has become a known fact that the allocated amounts by the National Student Financial Aid Scheme (NSFAS) and the available bursary funds within TUT, are clearly inadequate to meet students' financial needs. Many students are on a daily basis without food and basic 
necessities. Student supporters explained how these conditions cause embarrassment and stress for students and how impossible it is for them to focus on their studies.

According to one student supporter a female student admitted during the first conversation that she got involved in prostitution to buy food and clothes. The student supporter convinced the student to report to the SDS for professional counselling. The supporter remained involved throughout the rehabilitation process and ultimately the female student, with the necessary profesional counselling and financial assistance, changed to a healthy lifestyle.

Another supporter, while walking on the campus, met a young man who was an orphan and came with only his backpack from the deep rural areas of the Eastern Cape Province with the hope to receive financial assistance and be admitted into the university. Although he did not apply in advance, he was determined to wait. Without been noticed, he lived on the roof of a campus residence for several weeks. The student supporters organised temporary accommodation for the student and provided in his basic needs while arranging a meeting with the NSFAS officials. Eventually the young man succeeded to receive financial assistance, was allowed into a course and at the end of 2015 successfully completed his first year of study.

\section{Living conditions}

The majority of students, even those who are accommodated in TUT hostels at the campus, are complaining about their living conditions. The Soshanguve campus, before the dawn of democracy in 1994, formed part of the historically disadvantaged higher education institutions and although many resources have since been made available for the upgrading of this campus, it is still far from being an ideal living space for students. Protest actions are sometimes the result of students not being satisfied with the living conditions on campus. Student supporters, mostly also living in the hostels, are now the ones who report threatening situations in hostels to the faculty management.

\section{Socio-cultural and systemic factors}

Despite orientation programmes for new students at the beginning of the year, the lack of sufficient interaction between students and the academic, social and support systems of the university is probably the most important reason why students cannot cope with life at tertiary institutions. As a result of the Student Support Programme, the Faculty of Humanities, at the beginning of 2016 has intensified its first year orientation programme and is looking forward to determine the effect thereof soon. 


\subsection{Challenges faced and experiences gained by student supporters}

To trace some students is diffucult because of missing and incorrect contact details and students not responding to messages. Apart from the 19 hour per week appointment of student supporters, student supporters spend many additional hours moving around campus, in residences and sometimes even in classes to trace students at risk.

Winning the trust of some students and convincing them to open up, is a time consuming process; even more because of the stigma attached to students who were labelled by others as "poor performers" or "underperformers". Supporters sometimes also find it difficult to keep students motivated and not to withdraw from the support programmes.

The growing number of students seeking support, become impossible to manage. That impacts on infrastructure which requires a need for more private spaces to conduct interviews with students.

When posing the question to the student supporters "What have you learned and gained from your involvement in the Student Support Programme?” they were unanimous that this peer support programme is much more effective than the availability of "... highly qualified staff members waiting in their offices for students to report during their consultation hours". For the student supporters this journey was an enriching, but also an emotional experience. Although it was and still is not expected from student supporters to councel other students, it is clear that they often found themselves caught up in a situation where they are forced to give advice to their fellow students in need. Student supporters admitted that reaching out to their peers in this way was a life-changing experience. One student supporter was quite emotional when he remarked: "I believe that every single student that has been saved by my effort, is a life and a career that was saved. It definitely changed my life for ever."

\section{Conclusion}

The research question, "How effective is the Student Support Programme to enhance students' living and learning at a South African University?" was answered in the discussion of the findings. Although clear challenges still exist concerning the implementation of the Student Support Programme, the positive results and success stories are remarkable. A large number of students' living standards as well as their attitude towards academic matters and subsequently, their academic performance changed drastically because of the involvement and intervention of students supporters which resulted in the consecutive professional aid by the university's support systems. The 
Faculty acknowledges that this intervention must be continuously adapted and intensified to provide in the growing need for student support to enhance student success.

\section{References}

Council of Higher Education. (2013). A Proposal for Undergraduate Curriculum Reform in South Africa: The Case for a Flexible Curriculum structure. Report of the Task Team on Undergraduate Curriculum Structure. Pretoria.

Department of Higher Education and Training. (2011). Report on the Ministerial Committee for the Review of the Provision of Student Housing at South African Universities. Pretoria.

Department of Education. (2001). National Plan for Higher Education. Pretoria.

Leedy, P.D., \& Ormrod, J.E. 2005. Practical research. Planning and design. $8^{\text {th }}$ edition. Upper Saddle River: Pearson Merrill Prentice-Hall.

Lewin, T., \& Mawoyo, M. (2014). Student Access and Success: Issues and Interventions in South African Universities. The Kresge Foundation. Cape Town: Inyathelo.

Lynch, C. 2010. Doing your research project in sport. Southernhay East: Learning Matters Ltd.

Mertler, C.A. 2009. Action Research. Teachers as researchers in the classroom. $2^{\text {nd }}$ edition. Los Angeles: Sage Publications, Inc.

National Planning Commission. (2011). National Development Plan 2030: Our Future Make it Work. Pretoria.

Stringer, E.T. 2004. Action Research in Education. Upper Saddle River: Pearson Prentice Hall.

Tshwane University of Technology. 2015. The First Year Initial Experience Survey Report 2014. Pretoria: Tshwane University of Technology. 